\title{
Human Eosinophils Can Express the Cytokines Tumor Necrosis Factor- $\alpha$ and Macrophage Inflammatory Protein-1 $\alpha$
}

\author{
John J. Costa, * Karekine Matossian, " Murray B. Resnick, *" Waltraud J. Beil, * David T. W. Wong," John R. Gordon, * \\ Ann M. Dvorak, * Peter F. Weller, ${ }^{\star}$ and Stephen J. Galli* \\ Departments of * Pathology and ${ }^{\ddagger}$ Medicine, Beth Israel Hospital and Harvard Medical School, $\$$ Department of Pathology, \\ Brigham and Women's Hospital; and "Department of Oral Medicine and Oral Pathology, Harvard School \\ of Dental Medicine, Boston Massachusetts 02215
}

\begin{abstract}
By in situ hybridization, 44-100\% of the blood eosinophils from five patients with hypereosinophilia and four normal subjects exhibited intense hybridization signals for TNF- $\alpha$ mRNA. TNF- $\alpha$ protein was detectable by immunohistochemistry in blood eosinophils of hypereosinophilic subjects, and purified blood eosinophils from three atopic donors exhibited cycloheximide-inhibitable spontaneous release of TNF- $\alpha$ in vitro. Many blood eosinophils (39-91\%) from hypereosinophilic donors exhibited intense labeling for macrophage inflammatory protein$1 \alpha(M I P-1 \alpha)$ mRNA, whereas eosinophils of normal donors demonstrated only weak or undetectable hybridization signals for MIP-1 $\alpha$ mRNA. Most tissue eosinophils infiltrating nasal polyps were strongly positive for both TNF- $\alpha$ and MIP-1 $\alpha$ mRNA. By Northern blot analysis, highly enriched blood eosinophils from a patient with the idiopathic hypereosinophilic syndrome exhibited differential expression of TNF- $\alpha$ and MIP-1 $\alpha$ mRNA. These findings indicate that human eosinophils represent a potential source of TNF- $\alpha$ and MIP-1 $\alpha$, that levels of expression of mRNA for both cytokines are high in the blood eosinophils of hypereosinophilic donors and in eosinophils infiltrating nasal polyps, that the eosinophils of normal subjects express higher levels of TNF- $\alpha$ than MIP-1 $\alpha$ mRNA, and that eosinophils purified from the blood of atopic donors can release TNF- $\alpha$ in vitro. (J. Clin. Invest. 1993. 91:26732684.) Key words: chemokines • hypereosinophilia • in situ hybridization • inflammation • nasal polyps
\end{abstract}

\section{Introduction}

Eosinophils are granulocytes that mature in the bone marrow, circulate in the blood, and then enter the peripheral tissues. Eosinophils are particularly abundant beneath mucosal epithelial surfaces exposed to the external environment, such as the respiratory and gastrointestinal tracts $(1,2)$. Several disorders

Address correspondence and reprint requests to Stephen J. Galli, M.D., Director, Division of Experimental Pathology, Department of Pathology, The Beth Israel Hospital, 330 Brookline Avenue, Boston, MA 02215. Present address for John R. Gordon, Ph.D., is Department of Veterinary Microbiology, Western College of Veterinary Medicine, University of Saskatchewan, Saskatoon, Saskatchewan, Canada S7N ow0.

Received for publication 10 August 1992 and in revised form 22 December 1992.

J. Clin. Invest.

(C) The American Society for Clinical Investigation, Inc.

$0021-9738 / 93 / 06 / 2673 / 12 \$ 2.00$

Volume 91, June 1993, 2673-2684 are associated with increased numbers of circulating and/or tissue eosinophils $(3,4)$, including nasal polyposis; allergic asthma and other conditions with elements of immediate hypersensitivity; helminthic parasitic infections; certain neoplasms, connective tissue disorders, or immunodeficiency states; and the idiopathic hypereosinophilic syndrome (HES). ${ }^{1}$ HES comprises a heterogeneous group of disorders characterized by persistent blood eosinophilia of undefined etiology and the development of tissue infiltrates of eosinophils associated with dysfunction of the involved organs $(4,5)$. Eosinophils in the blood and tissues of patients with HES and other conditions associated with eosinophilia usually differ in several respects from the eosinophils in the blood of normal subjects, and exhibit functional and morphologic alterations indicative of in vivo activation. These differences include decreased cell density, increased numbers of cytoplasmic lipid bodies, enhanced metabolic activity, prolonged survival in vitro, and increased cytotoxicity against parasites and other target cells $(1-4)$.

In eosinophil-related disorders, including allergic and parasitic diseases and HES, eosinophils can promote inflammation through the release of a variety of pro-inflammatory mediators. These eosinophil-derived mediators include several distinct preformed cationic proteins located within cytoplasmic granules, and specific eicosanoids $(2,6)$. The recent discovery that eosinophils represent a potential source of several cytokines has suggested that these cells may influence inflammatory reactions and other biological responses through a broader spectrum of mechanisms than had previously been supposed (reviewed in reference 7). Del Pozo et al. (8) demonstrated that mouse peritoneal eosinophils stimulated with lipopolysaccharide (LPS) in vitro could produce IL- $1 \alpha$ mRNA and protein product. The first cytokine to be identified in human blood eosinophils or in eosinophils at sites of tissue pathology was TGF- $\alpha(9,10)$. TGF- $\alpha$ was detected by in situ hybridization in the eosinophils infiltrating the stroma of colonic adenocarcinomas, oral squamous cell carcinomas, and in the blood eosinophils of patients with hypereosinophilia (9). TGF- $\alpha$ expression has also been demonstrated in the eosinophils infiltrating carcinogen-induced squamous cell carcinomas in hamsters (10). Subsequently, several groups have presented evidence that human tissue or blood eosinophils represent potential sources of TGF- $\beta_{1}(11,12)$, GM-CSF $(13,14)$, IL-3 (14), IL-5 (15), IL-1 $\alpha$ (16), and IL-6 (17).

In the present study, we have determined whether human eosinophils represent a potential source of two proinflamma-

1. Abbreviations used in this paper: GAPDH, glyceraldehyde-3-phosphate dehydrogenase; HES, idiopathic hypereosinophilic syndrome; hTNF $\alpha$, human TNF $\alpha$; MIP, macrophage inflammatory protein. 
tory cytokines, TNF- $\alpha$ and macrophage inflammatory protein$1 \alpha(\mathrm{MIP}-1 \alpha)$. We were interested in TNF- $\alpha$ because several lines of evidence implicate this cytokine in the pathogenesis of allergic inflammation (18-25). We investigated MIP- $1 \alpha$ (also designated LD78 or pAT 464) because this cytokine also exhibits a number of proinflammatory effects, including the ability to induce macrophages to secrete TNF- $\alpha$, IL-6, and IL- $1 \alpha$ (26). Some of these findings have been presented in abstract form (27).

\section{Methods}

Human cells and tissues. We studied blood eosinophils from five eosinophilic donors and four normal adult male donors, and tissue eosinophils present in nasal polyp tissues resected from two patients. For in situ hybridization, unfractionated leukocytes, isolated from sodium citrate anticoagulated blood after erythrocyte depletion by dextran sedimentation and hypotonic lysis, as described previously (11), were obtained from one patient with HES (on three occasions), one patient with benign idiopathic hypereosinophila, one patient with eosinophilic gastroenteritis, and one child with hyper-IgE syndrome. These leukocytes, as well as nasal polyp tissue that had been immediately fixed in neutral-buffered formalin following surgical polypectomy, were processed for in situ hybridization as previously described (11). To permit a more direct comparison of the results of this study, which assessed expression of TNF- $\alpha$ or MIP- $1 \alpha$ by eosinophils, and the results of our recent study of TGF- $\beta_{1}$ expression by eosinophils (10), some of the preparations used in the present study were additional sections of the same specimens described in the previous study (11).

For Northern blots, granulocytes were isolated on two occasions from a donor with HES, and after dextran sedimentation and depletion of mononuclear leukocytes by sedimentation through Ficoll-Paque (Pharmacia Fine Chemicals, Piscataway, NJ) as previously described (28), yielded eosinophil-enriched granulocytes with 62 and $83 \%$ eosinophils, and with neutrophils constituting the only other contaminating leukocytes. For immunohistochemistry, leukocytes were obtained from the buffy coats of blood cells of two donors with HES on two separate dates.

Cell culture and stimulation. Freshly isolated eosinophil-enriched granulocytes were cultured for $0,1.5,6$, or $20 \mathrm{~h}\left(1 \times 10^{6}\right.$ cells $\left./ \mathrm{ml}\right)$ in RPMI medium with $10 \%$ FBS either without stimulation, or in the presence of the calcium ionophore A23187 $(1 \mu \mathrm{M})$ or PMA at 50 $\mathrm{ng} / \mathrm{ml}\left(8 \times 10^{-8} \mathrm{M}\right)$. At the indicated times, an aliquot of each culture suspension was removed, placed in $1 \%$ melted agarose, and processed for in situ hybridization as previously described (9). The remainder of each culture was harvested for Northern analysis as described below. The HL-60 cell line, originally derived from a patient with promyelocytic leukemia (29), was maintained at $37^{\circ} \mathrm{C}$ in a humidified atmosphere of $5 \% \mathrm{CO}_{2}$ in air, in RPMI medium supplemented with $10 \%$ FBS. HL-60 cells, which have been previously demonstrated to accumulate TNF- $\alpha$ mRNA in response to stimulation with PMA (30), were incubated $\left(2-3 \times 10^{6}\right.$ cells $\left./ \mathrm{ml}\right)$ in the presence or absence of PMA at $20 \mathrm{ng} / \mathrm{ml}\left(3 \times 10^{-8} \mathrm{M}\right)$ for 1,4 , or $24 \mathrm{~h}$.

Northern blot analysis. Purification of total RNA from eosinophilenriched granulocytes or HL-60 cells, and hybridization to membranes (Nitroplus; Micron Separations Inc., Westboro, MA), were carried out as previously described ( 31 ). Cells were lysed in guanidine thiocyanate and whole cell RNA was purified by $\mathrm{CsCl}$ gradient centrifugation. RNA agarose gels were loaded with $20 \mu \mathrm{g}$ per lane of total RNA from HL-60 cells and total RNA from $1 \times 10^{7}$ cell equivalents per lane of eosinophil-enriched granulocytes. The molecular probes used consisted of a 1.0-kb human TNF- $\alpha$ cDNA obtained from American Type Culture Collection (Rockville, MD), and a 0.73-kb human MIP-1 $\alpha$ cDNA obtained from S. Wolpe, Genetics Institute (Cambridge, MA), both of which were separately subcloned into a p Bluescript II SK ${ }^{-}$ vector (Stratagene, La Jolla, CA). A 1.2-kb chicken GAPDH cDNA obtained from G. Sonnenshein, Boston University Medical School
(Boston, MA) (32) was used to confirm the integrity and quantity of RNA on the Northern blots. cDNA probes were ${ }^{32} \mathrm{P}$-labeled by the random primer method as suggested by the manufacturer (Pharmacia Fine Chemicals). As noted above, in situ hybridization was used to identify the cellular source of cytokine mRNA in preparations used for Northern analysis.

In situ hybridization. In situ hybridization was performed as described (9), using conditions that avoided nonspecific binding of ${ }^{35} \mathrm{~S}$ labeled riboprobes to eosinophil granules and permitted specific labeling of eosinophil cytoplasmic mRNA. ${ }^{35}$ S-labeled sense and antisense human MIP- $1 \alpha$ or human TNF- $\alpha$ single-stranded riboprobes were prepared as suggested by the manufacturer (Promega, Madison, WI). The degree of hybridization was graded such that intense hybridization represented silver grain deposition over a cell in a $\geq 10$-fold excess above the background, weak hybridization represented a three- to ninefold number of silver grains over a cell in excess of background, and negative hybridization indicated no appreciable deposition of silver grains over a cell in excess of background. In situ hybridization slides were scored by microscopic examination of consecutive high power fields (final magnification $=400$ ) under ultraviolet illumination with and without a rhodamine filter until 100 eosinophils had been identified. Except where noted in the text, all in situ slides were scored for degree of hybridization after overnight autoradiographic exposure.

Immunohistochemistry. Immunohistochemical detection of TNF$\alpha$ protein was performed on duplicate specimens after fixation (in suspension) of buffy coat leukocytes in $2.5 \%$ paraformaldehyde in $0.1 \mathrm{M}$

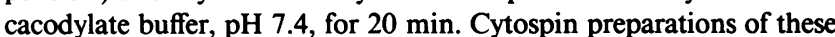
cells were briefly air dried and then incubated sequentially in $2 \%$ normal swine serum ( $20 \mathrm{~min}$ ) followed by a rabbit anti-human TNF- $\alpha$ antibody (catalog no. JP-300, Genzyme Corp., Cambridge, MA) for 2 $h$ in 0.12 M PBS, pH 7.4 (1:100 dilution). After washing in PBS, slides were incubated with a swine anti-rabbit biotinylated link antibody (Dako, Carpinteria, CA) (30 min; 1:40 dilution), washed again in PBS, and then exposed to alkaline phosphatase-conjugated $\mathrm{ABC}$-complex (Vector, Burlingame, CA) for $30 \mathrm{~min}$ in 0.5 M PBS, pH 7.2 (1:200 dilution ). The vector red substrate kit I (Vector Laboratories, Burlingame, CA ) for alkaline phosphatase, with $1 \mathrm{mM}$ levamisole added, was used for color development, and slides were then counterstained with 0.2\% aniline blue (CI42755; Fisher Scientific, Pittsburgh, PA) for 10 min to permit the unequivocal identification of eosinophils as previously described $(9,11,33)$. Controls were performed by replacing the anti-human TNF- $\alpha$ antibody with normal rabbit serum. The IgG concentration of these two reagents were equivalent.

Measurement of TNF- $\alpha$ production by eosinophils. We used an ELISA, which detects biologically active human TNF- $\alpha$ (Biosource International, Camarillo, CA) with a threshold sensitivity of $10 \mathrm{pg} / \mathrm{ml}$ to quantify the spontaneous production of TNF- $\alpha$ by human eosinophils in vitro. For these experiments, leukocytes were collected from three atopic but otherwise normal adult donors. Dextran-sedimented leukocytes were centrifuged for $20 \mathrm{~min}$ at $1,000 \mathrm{~g}$ on Ficoll Histopaque, density $1.083 \mathrm{~g} / \mathrm{ml}$ (Sigma Immunochemicals, St. Louis, MO). The mononuclear cell layer was aspirated and the granulocyte pellet was washed in calcium magnesium-free $\mathrm{HBSS}$ and incubated at $4^{\circ} \mathrm{C}$ for 60 min with anti-CD16 coated immunomagnetic particles (Miltenyi Biotec, Auburn, CA) as described in (34). Magnetically labeled neutrophils were then depleted using the MACS system (Miltenyi Biotec). Eosinophil preparations were $>98 \%$ pure with $<1 \%$ contaminating neutrophils or mononuclear cells, as assessed by differential cell counts of 200-500 cells that had been cytospun and stained by neutral red / fast green. As determined by the $\alpha$-naphthyl-acetate-esterase stain (Sigma), monocyte contamination was $0.0-0.5 \%$ ( $\geq 400$ leukocytes counted). Cells were incubated at $37^{\circ} \mathrm{C}$ and $5 \% \mathrm{CO}_{2}\left(2 \times 10^{6}\right.$ cells $\left./ \mathrm{ml}\right)$ in RPMI 1640 supplemented with $10 \%$ FBS in the presence or absence of cycloheximide $(100 \mu \mathrm{g} / \mathrm{ml})$ (Sigma). The amount of TNF- $\alpha$ in the supernatants of the eosinophils or mononuclear cells was measured after $18 \mathrm{~h}$ of culture. After collection of the supernatants, eosinophils were cytospun and examined by immunohistochemistry for TNF- $\alpha$ expression as noted above, except that glucose oxidase was used as the substrate. 


\section{Results}

Blood eosinophils of patients with hypereosinophilia demonstrate variable expression of TNF- $\alpha$ mRNA by in situ hybridization. We used in situ hybridization to determine which cell type in the peripheral blood of patients with hypereosinophilia might contain TNF- $\alpha$ mRNA. When peripheral blood leukocytes from the idiopathic HES patient were hybridized to the antisense TNF- $\alpha$ riboprobe, eosinophils exhibited intense labeling after only an overnight autoradiographic exposure (Fig. $1 a$ ). Fig. $1 b$ depicts the same field of this Giemsa-stained slide examined with ultraviolet light $(552 \mathrm{~nm})$ using a rhodamine filter, which enables eosinophils to be identified under these conditions by their characteristic bright red fluorescence $(9,11)$. Eosinophils were the only cell type detectably labeled with the TNF- $\alpha$ antisense probe (Fig. $1 b$ ). By contrast, an identically processed specimen exposed to the control TNF- $\alpha$ sense riboprobe demonstrated little or no hybridization to the eosinophils or to any other cell in this preparation (Fig. $1 c$ ), despite the presence of identifiable eosinophils, as confirmed by the Giemsa-enhanced fluorescence of these cells (Fig. $1 d$ ).

In situ hybridization analyses of two other granulocyte preparations from the HES patient, as well as eosinophil-enriched granulocytes from two other hypereosinophilic donors, also demonstrated specific hybridization of the TNF- $\alpha$ antisense riboprobe to eosinophils (Table I). As before, no cell type other than the eosinophil demonstrated specific hybridization to the TNF- $\alpha$ antisense probe. These in situ hybridization experiments established that human blood eosinophils from patients with differing etiologies for their hypereosinophilia contained mRNA for TNF- $\alpha$. In addition, we discovered variability in the percentage of eosinophils possessing strong hybridization signals. These data are summarized in Table I. 44-100\% of the eosinophils from the hypereosinophilic patients displayed a strong hybridization signal, with $\geq 60 \%$ of the eosinophils in each specimen clearly positive for the presence of TNF- $\alpha$ mRNA. However, each individual also exhibited a variable proportion of eosinophils that did not demonstrate any significant degree of hybridization to the TNF- $\alpha$ antisense probe. It was not uncommon to find a negative cell interspersed among several intensely positive cells, indicating that this observation did not reflect some artifact of probe distribution over the section during the hybridization procedure.

Blood eosinophils of normal subjects also express $T N F-\alpha$ $m R N A$. We next sought to determine if expression of TNF- $\alpha$ mRNA in blood eosinophils was restricted to individuals with hypereosinophilia. In our earlier studies of TGF- $\alpha(8)$ and TGF- $\beta_{1}(10)$ expression by human eosinophils, cells from normal donors labeled weakly, if at all, for the mRNA of these two cytokines. As seen in Fig. $1 e$, the peripheral blood eosinophils from one normal donor also demonstrated intense labeling with the TNF- $\alpha$ antisense riboprobe after only an overnight exposure. As with the hypereosinophilic patients, rhodamine fluorescence confirmed the identity of the positively labeled cells as eosinophils (Fig. $1 f$ ), and no other cell type was observed to possess a positive hybridization signal. Hybridization of this individual's cells with the control TNF- $\alpha$ sense probe yielded no labeling of eosinophils or other cell types (Fig. 1, $g$ and $h$ ).

Although the eosinophils of two other normal donors also demonstrated positive hybridization signals to the TNF- $\alpha$ antisense probe after overnight autoradiographic exposure, the in- tensity was less than that observed in the hypereosinophilic patients or the one normal subject depicted in Fig. 1. For example, in normal subjects 2 and 3 , only $12 \%$ of the eosinophils exhibited intensely positive hybridization signals after overnight autoradiographic exposure, compared to $77 \%$ for normal subject 1 or $44-100 \%$ for the hypereosinophilic subjects (Table I). When the data from subjects 2 or 3 were compared to those from normal subject 1 or from any of the hypereosinophilic subjects by the $\chi^{2}$ test, the results were significantly different $(P$ $<0.0001$ ) for all of the comparisons. We also used longer exposure times $(5 \mathrm{~d})$ to assess the percentages of eosinophils that displayed intense, weak or no hybridization signals in preparations from normal subjects 2-4 (Table I). As had been observed with the eosinophilic patients, the normal donors also demonstrated variability in the number of silver grains present over the eosinophils in these preparations. Once again, no cell other than the eosinophil demonstrated a positive hybridization signal, and there was no specific labeling of any cell type observed with the sense probe. Taken together with the data from the eosinophilic donors, these findings suggest that within a population of human blood eosinophils, there can be differential TNF- $\alpha$ gene expression. Moreover, the presence of some unlabeled eosinophils in the sections hybridized to the TNF- $\alpha$ antisense riboprobe and the lack of eosinophil hybridization to the TNF- $\alpha$ sense probe argues against the notion that the positive hybridization signals observed with the antisense probe are an artifact resulting from the nonspecific binding of the labeled nucleic acid probes to the highly charged eosinophil granule proteins.

Human eosinophils express $T N F-\alpha$ protein by immunohistochemistry. To demonstrate that TNF- $\alpha$ mRNA may be translated into protein product by eosinophils, we examined peripheral blood leukocytes obtained on two separate occasions from each of two different hypereosinophilic donors for evidence of immunohistochemically detectable TNF- $\alpha$. Buffy coat leukocytes stained with a polyclonal rabbit anti-TNF- $\alpha$ antibody and immunoalkaline phosphatase demonstrated TNF- $\alpha$ protein detectable within eosinophils (Fig. $2 a$ ). The identity of the cells exhibiting staining for TNF- $\alpha$ as eosinophils was confirmed by aniline blue fluorescent staining of their cytoplasmic granules (Fig. $2 b$ ). In the four preparations analyzed, $70-80 \%$ of the eosinophils exhibited detectable staining for TNF- $\alpha$ protein. Control rabbit antibody, substituted in lieu of anti-TNF- $\alpha$ antibody, yielded no staining of eosinophils or other cell types (Fig. 2, $c$ and $d$ ). Other noneosinophilic blood leukocytes usually did not exhibit immunostaining for TNF- $\alpha$ (Fig. $2 a$ ). Induction of TNF- $\alpha$ message and bioactivity has been observed in human peripheral blood neutrophils stimulated with either lipopolysaccharide or Candida albicans (35, 36). Occasional neutrophils in our preparations $(<10 \%)$ exhibited equivocal staining with the anti-TNF antibody (not shown). This presumably reflects retention by these cells of previously translated TNF- $\alpha$ protein product, since none of the in situ hybridization studies from either hypereosinophilic or normal donors revealed labeling over any cell other than eosinophils. These findings establish that blood eosinophils from hypereosinophilic donors can contain immunoreactive TNF- $\alpha$ protein product, as well as TNF- $\alpha$ mRNA.

Human eosinophils release $T N F-\alpha$. We investigated whether peripheral blood eosinophils purified from atopic donors released detectable TNF- $\alpha$ activity during an 18-h period of culture in vitro at $2 \times 10^{6}$ cells $/ \mathrm{ml}$ ( Table II). Eosinophil 

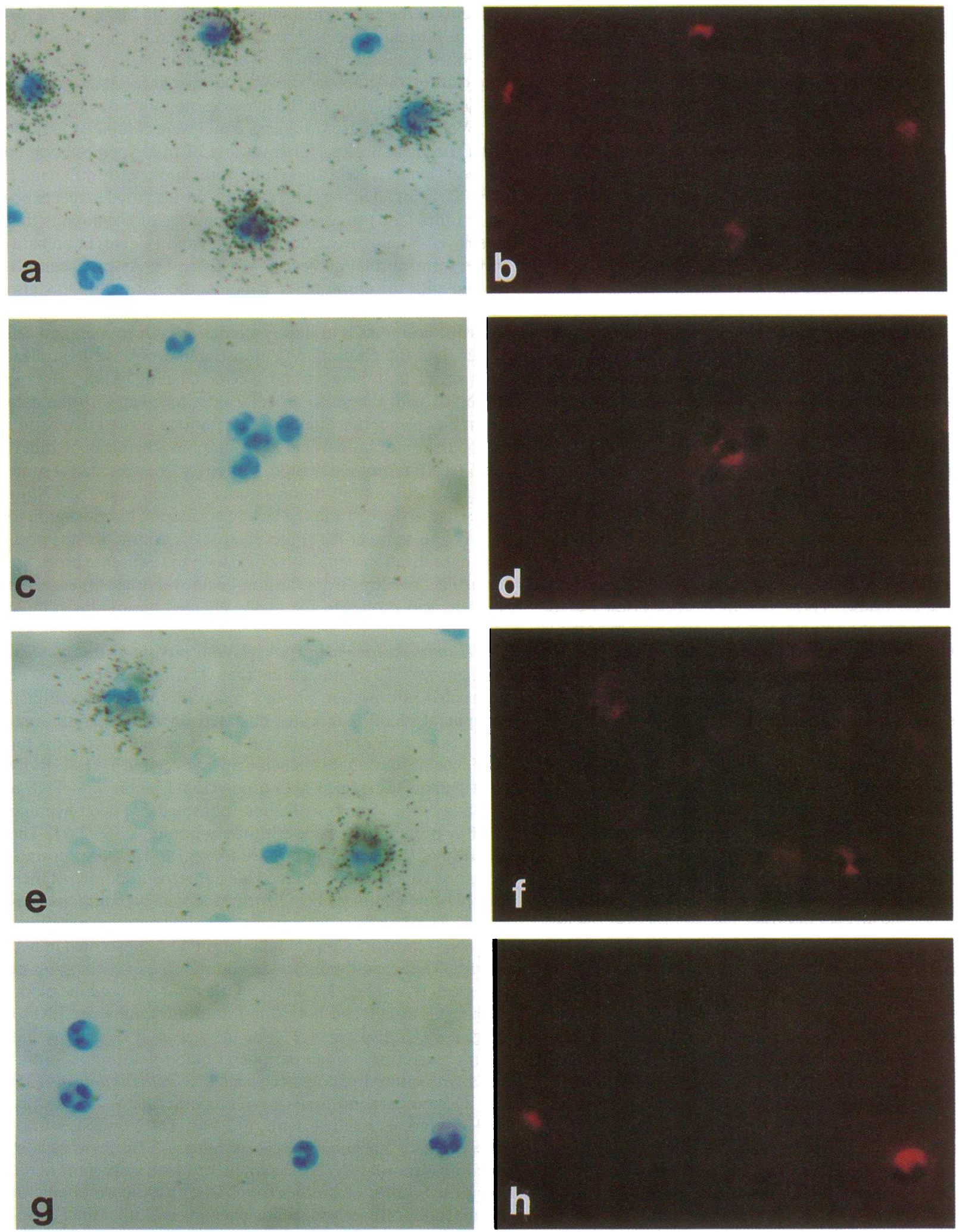

Figure 1. Localization of cellular sources of TNF- $\alpha$ mRNA in peripheral blood leukocyte preparations by in situ hybridization. Eosinophilenriched granulocyte preparations from a patient with HES $(a-d)$ or a normal donor $(e-h)$. Bright field visualization of sections hybridized to the ${ }^{35}$ S-labeled antisense human TNF- $\dot{\alpha}$ (hTNF- $\alpha$ ) riboprobe ( $a$ and $e$ ) or to the ${ }^{35}$ S-labeled sense hTNF- $\alpha$ riboprobe $(c$ and $g$ ), and then stained with Giemsa. Autoradiographic exposure time was for $24 \mathrm{~h}$ at $4^{\circ} \mathrm{C} .(b, d, f$, and $h)$ Fluorescent visualization of the same four fields shown in $a, c, e$, and $g$, respectively, using a rhodamine filter to demonstrate the Giemsa-enhanced fluorescence of human eosinophils. $a-h, \times 500$. 
Table I. Percentage of Eosinophils that Express $m R N A$ for TNF- $\alpha$ or MIP-I $\alpha$ by In Situ Hybridization

\begin{tabular}{|c|c|c|c|c|c|c|}
\hline \multirow[b]{2}{*}{ Subjects } & \multicolumn{3}{|c|}{ TNF- $\alpha(\%)$} & \multicolumn{3}{|c|}{$\operatorname{MIP}-1 \alpha(\%)$} \\
\hline & Intensely positive & Weakly positive & Negative & Intensely positive & Weakly positive & Negative \\
\hline \multicolumn{7}{|l|}{ Hypereosinophilic } \\
\hline \multicolumn{7}{|l|}{ 1. HES* } \\
\hline Sample 1 & $88^{\ddagger}$ & 6 & 6 & 82 & 14 & 4 \\
\hline Sample 2 & 100 & 0 & 0 & 91 & 6 & 3 \\
\hline Sample $3^{\| \prime}$ & 58 & 13 & 29 & 66 & 18 & 16 \\
\hline 2. Benign hypereosinophilia & ND & ND & ND & 39 & 29 & 32 \\
\hline 3. Hyper IgE syndrome & $44^{\ddagger}$ & 16 & 40 & $(44)^{\S}$ & (18) & (38) \\
\hline 4. Eosinophilic gastroenteritis & 55 & 18 & 27 & 69 & 16 & 15 \\
\hline \multicolumn{7}{|l|}{ Normal } \\
\hline 1. & 77 & 13 & 10 & (28) & (42) & (30) \\
\hline 2. & $12(48)$ & $28(13)$ & $60(39)$ & (12) & (33) & $(55)$ \\
\hline 3. & $12(76)$ & $20(4)$ & $67(20)$ & $(0)$ & (11) & (89) \\
\hline 4. & ND (83) & ND (11) & ND (6) & $(0)$ & $(25)$ & (75) \\
\hline
\end{tabular}

* Three specimens (samples 1-3) were obtained from the same patient on three different occasions. ${ }^{\ddagger} 50$ consecutive eosinophils were scored. In all other instances, 100 eosinophils were scored. ${ }^{5}$ Values in parentheses are from specimens evaluated after a 5-d exposure; all other specimens were evaluated after an overnight exposure. "Purified over Ficoll-Hypaque; all other specimens were prepared by dextran sedimentation and hypotonic lysis of erythrocytes. ND, Not done.

preparations were $>98 \%$ pure with $<1 \%$ contaminating neutrophils or mononuclear cells and $<0.5 \%$ monocytes as determined by the nonspecific esterase technique. Supernatants from mononuclear cells isolated from the same donors were used as positive controls. Eosinophil supernatants showed detectable activity ranging from $60-218 \mathrm{pg} / \mathrm{ml}$. Thus, under these conditions of culture, eosinophils produced on average $\sim 12 \%$ as much TNF- $\alpha$ as did mononuclear cells. Considering that monocytes represented $<0.5 \%$ of the cells in the eosinophil-enriched preparations, monocytes probably did not account for the TNF- $\alpha$ detected in the eosinophil supernatants. Moreover, immunohistochemical examination of eosinophils after the collection of supernatants demonstrated TNF- $\alpha$ immunoreactivity in $\sim 50 \%$ of the eosinophils. These data confirm that highly purified eosinophils separated from normal donors can release TNF- $\alpha$ during in vitro culture. Addition of cycloheximide $(100 \mu \mathrm{g} / \mathrm{ml})$ completely inhibited production of detectable TNF- $\alpha$ by the eosinophil preparations and virtually eliminated release of TNF- $\alpha$ by the mononuclear cell preparations ( Table II), indicating that the release of TNF- $\alpha$ by these cells required protein synthesis. According to assessment of trypan blue exclusion, cycloheximide had little or no effect on cell viability.

Blood eosinophils from hypereosinophilic patients, but not normal subjects, express high levels of $M R N A$ for MIP-1 $\alpha$ by in situ hybridization. To evaluate whether eosinophils might be capable of forming another proinflammatory cytokine, MIP$1 \alpha$, we evaluated peripheral blood leukocytes from eosinophilic and normal donors for evidence of MIP- $1 \alpha$ mRNA expression. By in situ hybridization with a MIP-1 $\alpha$ antisense riboprobe, we observed intense labeling of eosinophils from a donor with HES (Fig. 3, $a$ and $b$ ). Moreover, exposure of these same specimens to control ${ }^{35} \mathrm{~S}$-labeled MIP- $1 \alpha$ sense probes resulted in no detectable hybridization to any cell type (Fig. 3, c and $d$ ). Similarly, in situ hybridization detected specific ex- pression of mRNA for MIP- $1 \alpha$ within eosinophils from three other eosinophilic donors (Table I). All were found to contain large percentages of eosinophils with positive hybridization signals for MIP- $1 \alpha$, with a range of 39-91\% of eosinophils exhibiting intense labeling for MIP- $1 \alpha$ mRNA. No cells other than eosinophils were labeled by the MIP- $1 \alpha$ antisense probe. As with TNF- $\alpha$, there was considerable variation among individual subjects in the percentage of intensely labeled eosinophils (Table I), suggesting heterogeneity in the expression of MIP$1 \alpha$ as well.

When the eosinophils from normal donors were examined, the same donor whose eosinophils had demonstrated intense hybridization signals for TNF- $\alpha$ after only an overnight exposure displayed no eosinophils or other cells that hybridized to the MIP- $1 \alpha$ antisense riboprobe. Prolongation of the exposure time to $5 \mathrm{~d}$ revealed the presence of a population of positively labeled eosinophils, but the percentage of positive cells and the intensity of the hybridization signal were much less than that observed with TNF- $\alpha$ (Table I and Fig. 3,e-h). Once again, even with prolonged exposure, no cell type other than eosinophils hybridized to the MIP- $1 \alpha$ antisense probe. In situ hybridization studies of leukocytes from three other normal donors demonstrated only low percentages of weak MIP-1 $\alpha$ labeling after 5-d autoradiographic exposures (Table I), whereas strong hybridization signals had been observed after identical durations of exposure to the TNF- $\alpha$ antisense probe. Thus, the expression of MIP- $1 \alpha$ mRNA by human eosinophils appears similar to the previously described expression of TGF- $\alpha$ (9) and TGF- $\beta_{1}(11)$ by this cell type. For all three of these cytokines, expression of mRNA is much greater in blood eosinophils derived from hypereosinophilic patients than in eosinophils from normal subjects.

Eosinophils infiltrating nasal polyps express $m R N A$ for $T N F$ - $\alpha$ and $M I P-1 \alpha$. Since in situ hybridization analysis clearly demonstrated the presence of mRNA for both TNF- $\alpha$ and 

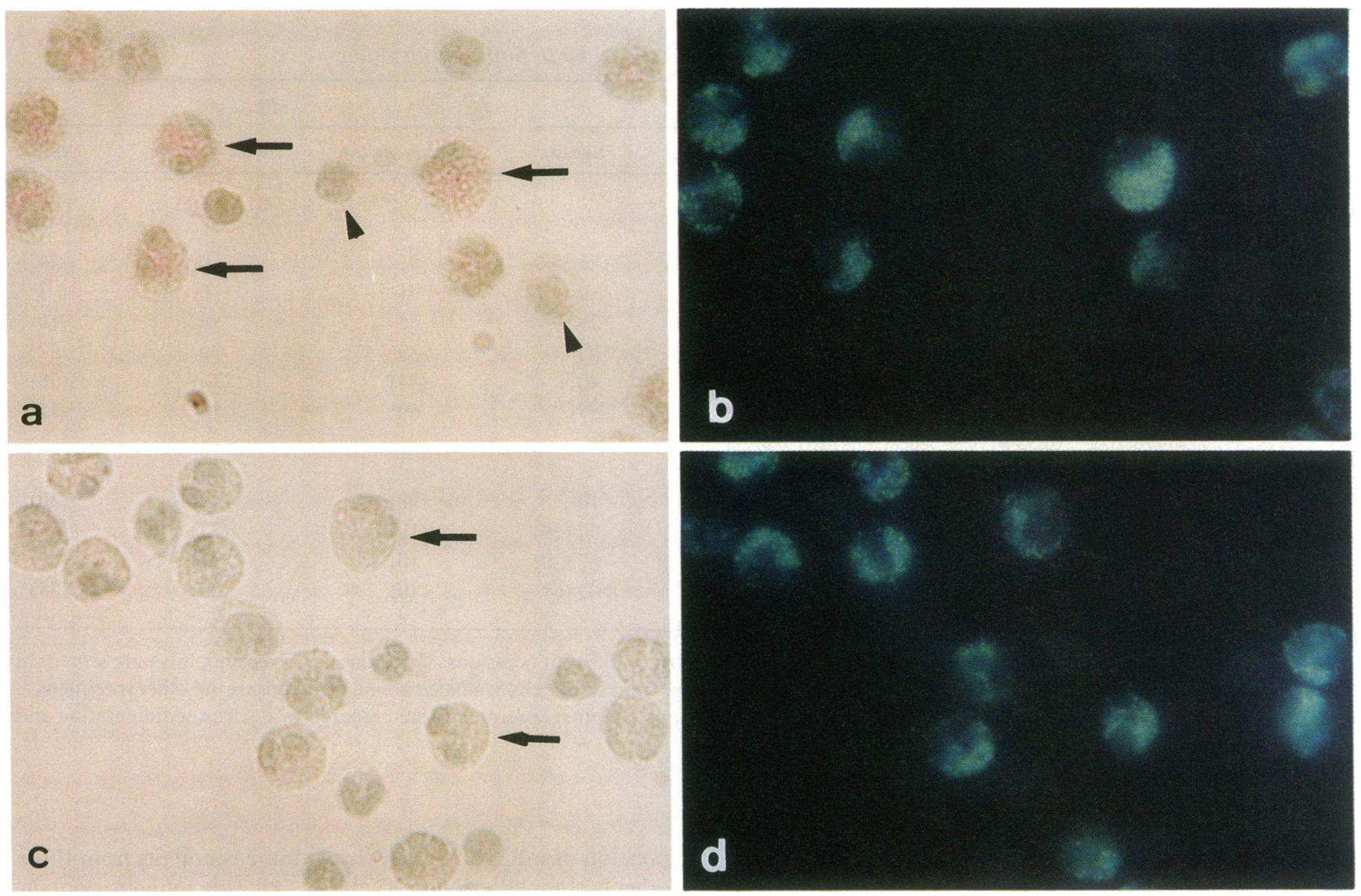

Figure 2. Immunohistochemical detection of human TNF- $\alpha$ protein in peripheral blood leukocytes from a patient with HES. Bright field examination of cells stained with anti-hTNF- $\alpha$ antiserum $(a)$ or control serum $(c)$. ( $b$ and $d)$ Visualization of the same two fields shown in a and $c$ by fluorescence microscopy at $365 \mathrm{~nm}$ with a 4,6 diamidino-2-phenylindole filter to demonstrate the aniline blue fluorescence of eosinophils. (a) Only the eosinophils (three of them indicated by arrows) demonstrate staining with the anti-hTNF- $\alpha$ antiserum whereas peripheral blood mononuclear cells (two of them indicated by arrowheads) do not. (c) Neither eosinophils (two of them indicated by arrows) nor any other cells stained with the control antiserum. $a-d, \times 735$.

MIP-1 $\alpha$ within peripheral blood eosinophils, we next evaluated whether eosinophils infiltrating lesions in vivo also contained detectable transcripts for these two cytokines. Nasal polyps, which typically are eosinophil-enriched lesions, were examined by in situ hybridization for the cellular expression of TNF- $\alpha$ and MIP-1 $\alpha$. Eosinophils within the nasal polyps resected from two patients specifically hybridized to the ${ }^{35}$ S-labeled TNF- $\alpha$ antisense probe (Fig. 4, $a$ and $b$ ), but not to the control sense probe (Fig. 4, $c$ and $d$ ). Although there was some variability in the intensity of grains over the eosinophils in this specimen, the vast majority of eosinophils displayed intense hybridization signals. No other cell type within these sections appeared to hybridize to the TNF- $\alpha$ antisense probe. Exposure of the nasal polyp tissue to the MIP- $1 \alpha$ probes yielded similar results. Intense labeling of eosinophils by the MIP-1 $\alpha$ antisense probe was observed after only an overnight exposure. Even when autoradiographic exposure of these sections was extended to $5 \mathrm{~d}$, no cell type other than the eosinophil was positively labeled

Table II. Measurement of TNF- $\alpha$ in Supernatants of Peripheral Blood Eosinophils or Mononuclear Cells after 18 h Culture In Vitro

\begin{tabular}{|c|c|c|c|c|c|}
\hline \multirow[b]{2}{*}{ Cells* } & \multicolumn{5}{|c|}{ TNF- $\alpha$} \\
\hline & Cycloheximide & Experiment 1 & Experiment 2 & Experiment 3 & Mean \pm SEM \\
\hline & \multicolumn{5}{|c|}{$p g / m l$} \\
\hline Eosinophils & - & 218 & 89 & 60 & $122 \pm 63$ \\
\hline Eosinophils & + & $<10$ & $<10$ & $<10$ & $<10$ \\
\hline Mononuclear cells & - & 1,140 & 1,202 & 620 & $987 \pm 245$ \\
\hline Mononuclear cells & + & 15 & 22 & ND & $18 \pm 3$ \\
\hline
\end{tabular}

* In each experiment, purified eosinophils or mononuclear cells derived from the same subject were incubated $\left(2 \times 10^{6} \mathrm{cells} / \mathrm{ml}\right)$ for $18 \mathrm{~h}$ in culture medium in the presence or absence of cycloheximide $(100 \mu \mathrm{g} / \mathrm{ml})$. Cell-free supernatants were assayed for TNF- $\alpha$ activity as described in Methods. ND, Not done. 

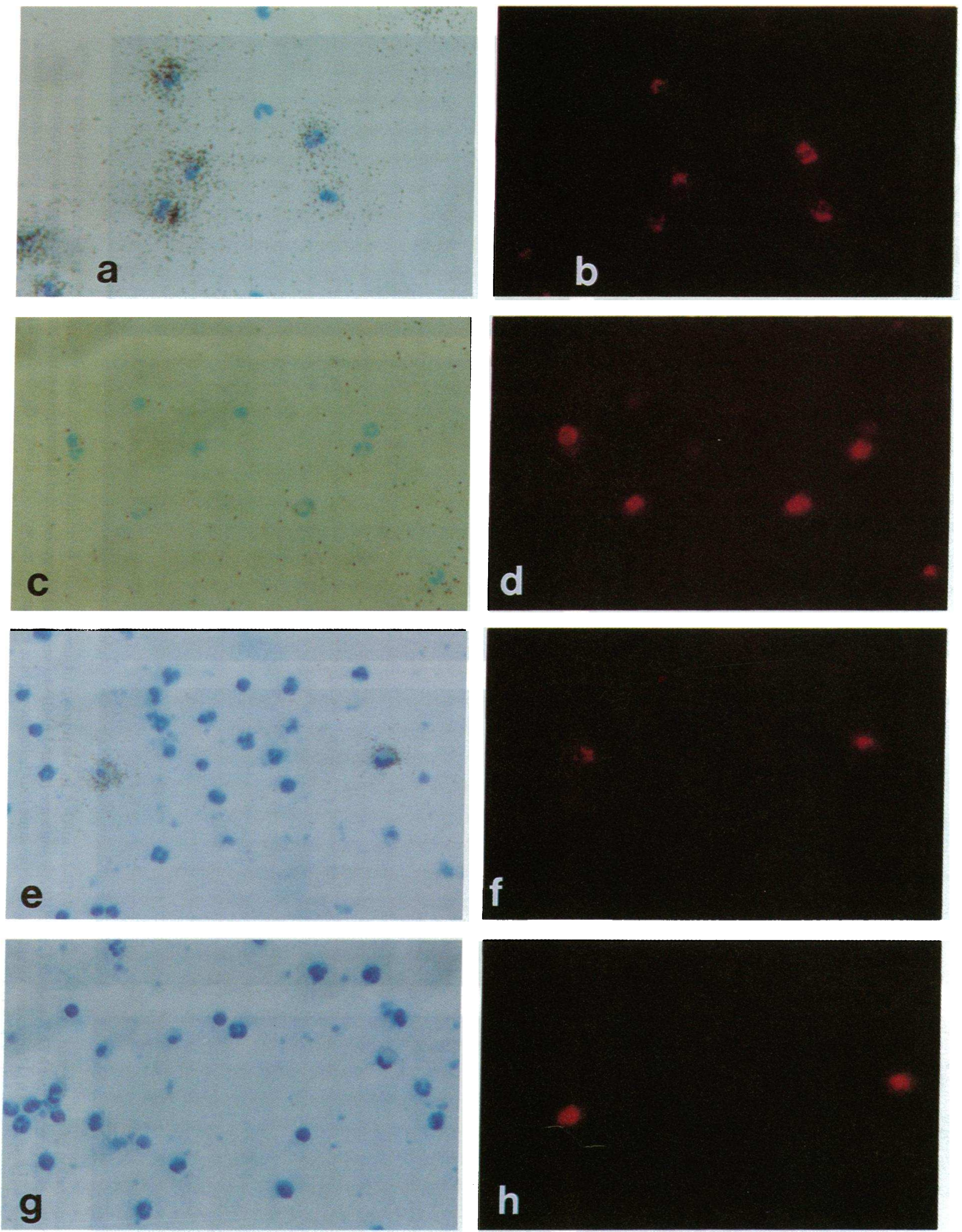

Figure 3. Localization of cellular sources of MIP-1 $\alpha$ mRNA in peripheral blood leukocyte preparations by in situ hybridization. Eosinophilenriched granulocyte preparations from a patient with HES $(a-d)$ or a normal donor $(e-h)$. Bright field visualization of sections hybridized to the ${ }^{35} \mathrm{~S}$-labeled antisense human macrophage inflammatory protein-1 $\alpha(\mathrm{hMIP}-1 \alpha)$ riboprobe $(a$ and $e)$ or to the ${ }^{35} \mathrm{~S}$-labeled sense hMIP-1 $\alpha$ riboprobe ( $c$ and $g$ ), and then stained with Giemsa. Autoradiographic exposure time was for $24 \mathrm{~h}(a$ and $c)$ or $5 \mathrm{~d}(e$ and $g)$ at $4{ }^{\circ} \mathrm{C}$. $(b, d, f$, and $h$ ) Fluorescent visualization of the same four fields shown in $a, c, e$, and $g$, respectively, using a rhodamine filter to demonstrate the Giemsa-enhanced fluorescence of human eosinophils. $a-h, \times 312$. 

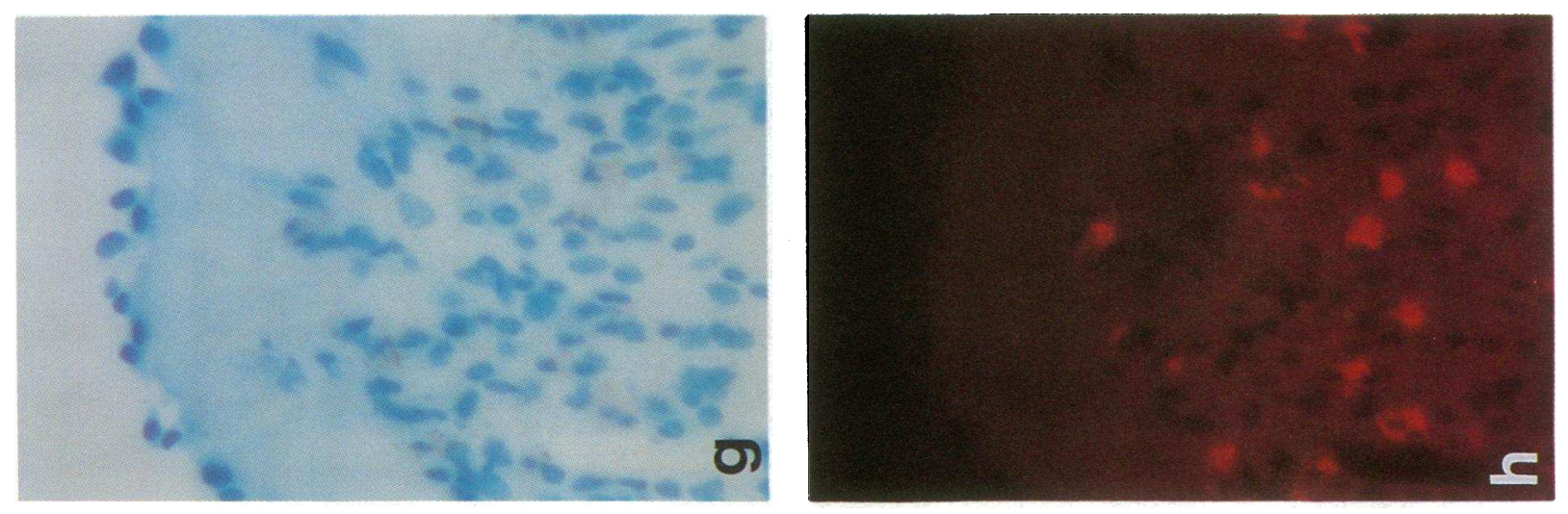

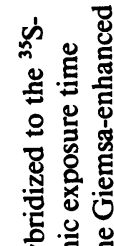

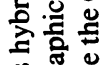

悹

啳

嗐

5 8

E
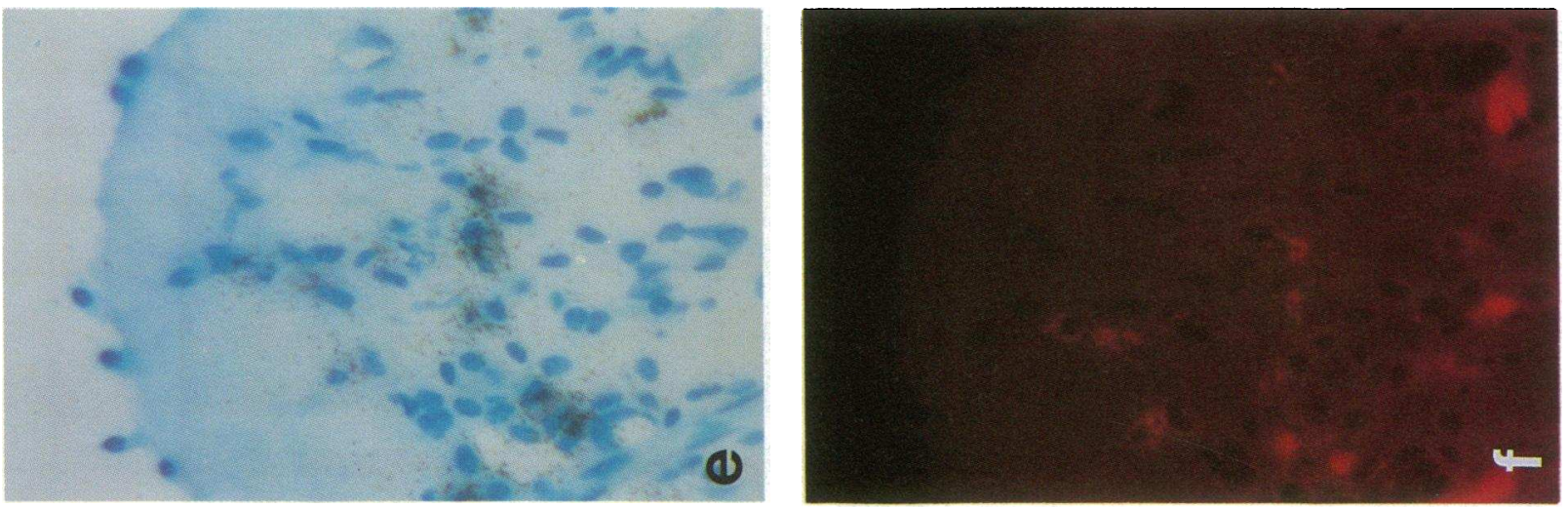

为

讨

돌

훙

들

के

동

글 충

응

웅

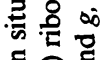

$\triangle$ का

ô.

挽

.
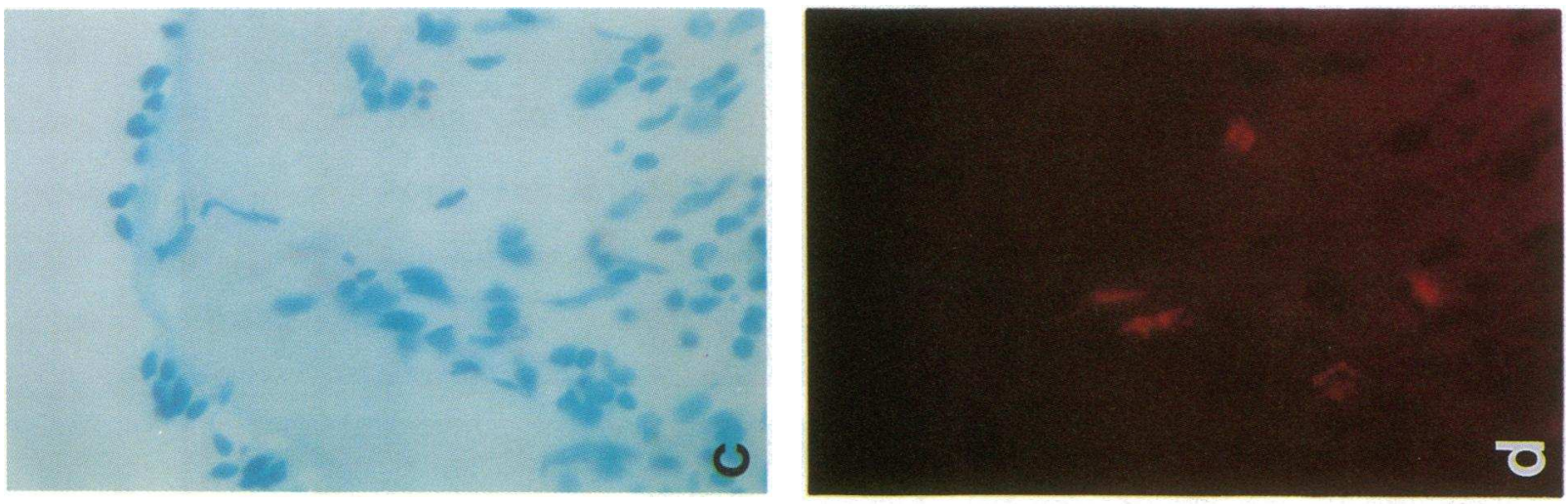

20

롤

哥 总

$\Xi$ Q

중

龸总

웡

훙

害

돌

ड़

之兽旁

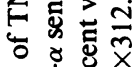
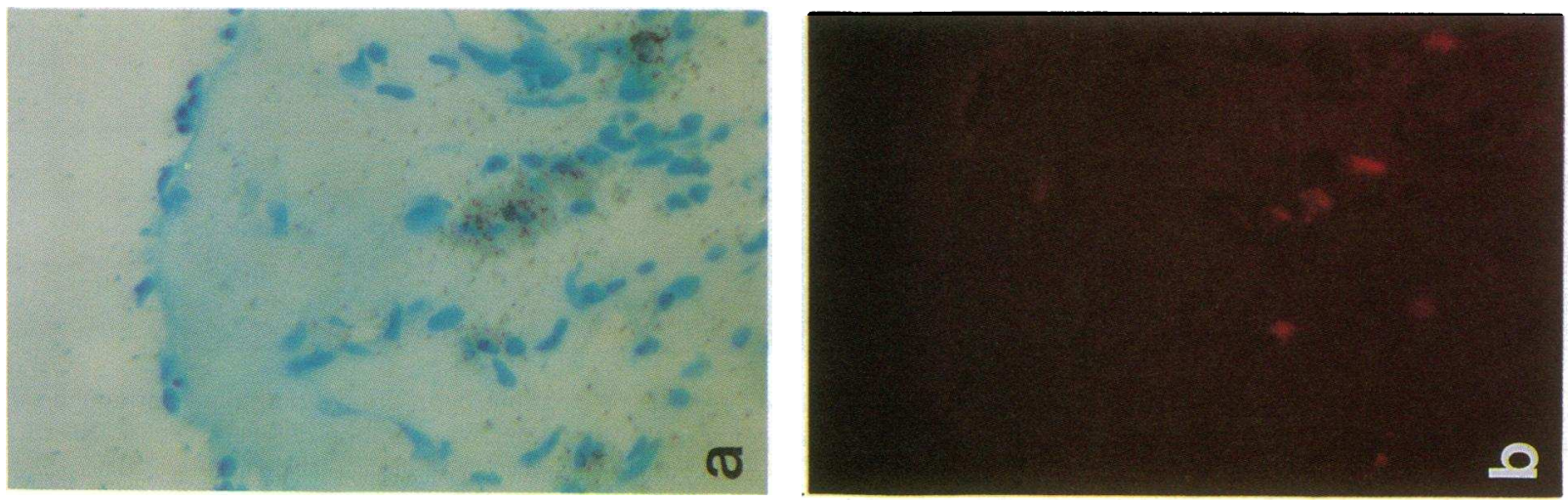

过崖

娄方

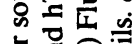

点寡

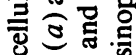

¿

a

氧产

월

ชั

更

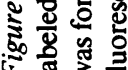


with the MIP-1 $\alpha$ antisense probe (Fig. 4, $e$ and $f$ ), nor was there significant hybridization to the control MIP- $1 \alpha$ sense probe (Fig. 4, $g$ and $h$ ). Taken together, these data demonstrate that human eosinophils resident in tissues can contain abundant mRNA for both TNF- $\alpha$ and MIP- $1 \alpha$.

Differential expression of $M R N A$ for $T N F-\alpha$ and MIP-1 $\alpha$ in blood eosinophils from a patient with idiopathic HES. The observation that large numbers of eosinophils from the hypereosinophilic patients or within nasal polyp tissue displayed intense hybridization signals for both TNF- $\alpha$ and MIP-1 $\alpha$ mRNA, whereas eosinophils from normal subjects expressed mRNA for TNF- $\alpha$ to a much greater extent than MIP- $1 \alpha$ suggested that these cytokines might be subject to differential regulation. To examine this possibility, we used Northern analysis to determine the relative levels of mRNA for these two cytokines in eosinophil-enriched granulocytes from an HES donor. The experiment was performed twice, with both experiments yielding the same results.

Total RNA isolated from eosinophil-enriched granulocytes contained an intense TNF- $\alpha$ hybridization signal (Fig. 5, lane 5 ). The molecular size of the human granulocyte TNF- $\alpha$ message was identical to that present in HL-60 cells both before (Fig. 5, lane 1) and especially after PMA induction (lanes 2 and 3). By comparison with RNA size standards, both the HL-60 and the human eosinophil-enriched granulocyte TNF$\alpha$ mRNAs were $\sim 1.7 \mathrm{~kb}$, as expected. The steady-state level of TNF- $\alpha$ mRNA in eosinophils decreased $1.5 \mathrm{~h}$ after incubation of freshly isolated eosinophils in media supplemented with FBS but without additional exogenous growth factors (lane 6). However, levels of TNF- $\alpha$ mRNA were sustained equally well in the cultures that had been stimulated by addition of either calcium ionophore or PMA for $1.5 \mathrm{~h}$ (lanes 7 and 8 ). Although TNF- $\alpha$ expression was maintained through $6 \mathrm{~h}$ in the ionophore- or PMA-stimulated cells (lanes 9 and 10), after $20 \mathrm{~h}$ of culture, neither the unstimulated cells nor those to which iono-

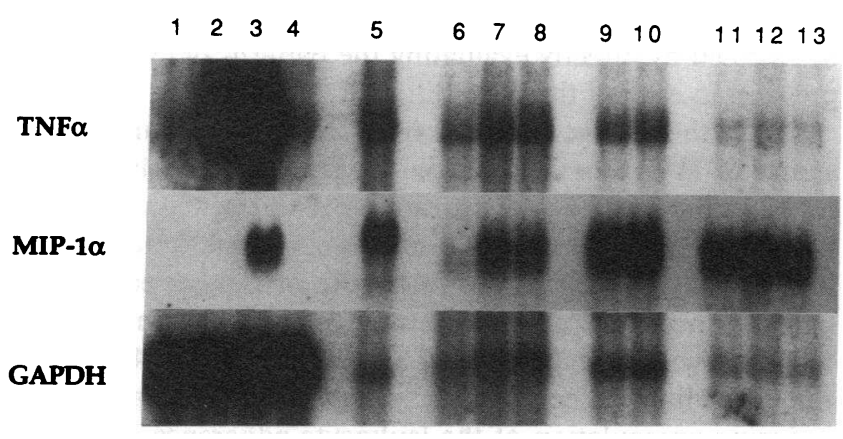

Figure 5. Northern blot analysis of peripheral blood leukocytes from a patient with HES. As a control, we also examined $20 \mu \mathrm{g}$ of total RNA from unstimulated HL-60 cells (lane 1), or HL-60 cells cultured in the presence of $20 \mathrm{ng} / \mathrm{ml}$ PMA for $1 \mathrm{~h}$ (lane 2), $4 \mathrm{~h}$ (lane 3) or $24 \mathrm{~h}$ (lane 4). (Lanes 5-13) Eosinophil-enriched granulocyte preparations (62\% eosinophils, $38 \%$ neutrophils) obtained after dextran sedimentation and centrifugation through Ficoll-Hypaque. Cells were harvested for total RNA immediately (lane 5) or after $1.5 \mathrm{~h}$ (lanes 6-8), $6 \mathrm{~h}$ (lanes 9 and 10) or $20 \mathrm{~h}$ (lanes 11-13) of culture in RPMI medium with $10 \%$ FBS. The cells in lanes 7,9 , and 12 were stimulated with the calcium ionophore A23187, at a final concentration of 1 $\mu \mathrm{M}$. The cells in lanes 8,10 , and 13 were stimulated with PMA, at a final concentration of $50 \mathrm{ng} / \mathrm{ml}$. phore or PMA had been added demonstrated significant levels of TNF- $\alpha$ message (lanes 11-13).

Fig. 5 also depicts the same Northern blot stripped and re-probed for MIP- $1 \alpha$ gene expression. In contrast to TNF- $\alpha$, expression of MIP-1 $\alpha$ by HL-60 cells was not observed in unstimulated cells (lane 1 ) and was only detected in the cultures stimulated with PMA for $4 \mathrm{~h}$ (lane 3). However, there was an intense MIP-1 $\alpha$ hybridization signal of the appropriate size $(\sim 0.8 \mathrm{~kb})$ in freshly isolated eosinophil-enriched granulocytes (lane 5). As had been observed with TNF- $\alpha$, short-term culture $(1.5 \mathrm{~h})$ of these cells in media alone resulted in near-complete loss of MIP-1 $\alpha$ message (lane 6 ), but both calcium ionophore and PMA stimulated sustained MIP- $1 \alpha$ mRNA expression (lanes 7 and 8 ). We observed enhanced induction of MIP-1 $\alpha$ expression after $6 \mathrm{~h}$ of culture in the presence of either ionophore or PMA (lanes 9 and 10) as compared to the intensity of the hybridization signal from the freshly isolated cells (lane 5 ). In addition, after $20 \mathrm{~h}$ of culture in media without exogenous growth factors, a strong MIP-1 $\alpha$ mRNA band was observed (lane 11). A hybridization signal of similar intensity was also detected in the cultures stimulated with calcium ionophore or PMA for $20 \mathrm{~h}$ (lanes 12 and 13).

The Northern blot was then stripped and reprobed to assess glyceraldehyde-3-phosphate (GAPDH) gene expression. GAPDH transcript levels are relatively constant among various cell types and are refractory to induction (37). Comparison of the GAPDH hybridization signals from the HL- 60 cells (20 $\mu \mathrm{g}$ total RNA) and the peripheral blood granulocytes clearly demonstrated that the RNA in the granulocyte preparations was intact, although they contained smaller quantities of RNA than did the HL- 60 preparations. In this light, the intensities of the TNF- $\alpha$ and MIP- $1 \alpha$ hybridization signals in the freshly isolated, unstimulated granulocyte preparation were proportionally greater than would be expected based on the different quantities of RNA loaded in the gel. This is consistent with the in situ hybridization findings, and suggests that the eosinophils from this HES patient constitutively contained relatively high levels of these messages. Similarly, given the faint GAPDH bands observed in the $20 \mathrm{~h}$ cultures, the strong MIP$1 \alpha$ hybridization signals detected indicate that there were relatively high levels of MIP- $1 \alpha$ mRNA in these cells. In fact, in situ hybridization analysis of the cells from the $20 \mathrm{~h}$ cultures for MIP- $1 \alpha$ revealed a positive hybridization signal in $72-84 \%$ of these eosinophils, with $31-50 \%$ displaying intense labeling of these cells. Thus, even within a population of eosinophils with a high level of constitutive cytokine gene expression, either calcium ionophore- or protein kinase $\mathrm{C}$-dependent activation appear able to increase and/or sustain expression of MIP- $1 \alpha$ mRNA, while induction of TNF- $\alpha$ mRNA appears more transient.

It should be noted that these preparations of eosinophilenriched granulocytes contained neutrophils as the only identifiable contaminating cell, which raised the possibility that the hybridization signal observed on the Northern blot represented mRNA that was not of eosinophil origin. The earlier in situ work, which failed to reveal any positive hybridization signals for TNF- $\alpha$ or MIP- $1 \alpha$ in the neutrophils from hypereosinophilic or normal donors made this seem unlikely. Nevertheless, we used in situ hybridization to examine cytokine message expression in both the freshly isolated eosinophil-enriched granulocytes, as well as in those cultures stimulated with either calcium 
ionophore or PMA for $20 \mathrm{~h}$. No cell other than the eosinophil demonstrated a positive hybridization signal for either of these cytokines. These data strongly suggest that the hybridization signals observed on the Northern blots primarily reflect the levels of TNF- $\alpha$ and MIP- $1 \alpha$ mRNAs present within the eosinophils in these cultures.

\section{Discussion}

We found that blood eosinophils from patients with hypereosinophilia, as well as eosinophils infiltrating nasal polyps, express intense hybridization signals for TNF- $\alpha$ and MIP- $1 \alpha$ mRNA, and that the eosinophils of hypereosinophilic donors contain TNF- $\alpha$ protein which is detectable by immunohistochemistry. In addition, we showed that $>98 \%$ pure preparations of blood eosinophils from atopic but otherwise normal donors spontaneously release TNF- $\alpha$ protein during overnight culture in vitro. The amount of TNF- $\alpha$ released by these eosinophils was $\sim 12 \%$ that released under identical culture conditions by blood mononuclear cells from the same subjects. The release of TNF- $\alpha$ by either the purified eosinophils or the mononuclear cells was inhibited virtually entirely by cycloheximide, indicating that such TNF- $\alpha$ production required protein synthesis.

Beyond demonstrating that human eosinophils represent a potential source of TNF- $\alpha$ and MIP- $1 \alpha$, this study has uncovered several other new facets of cytokine gene expression by eosinophils. The in situ hybridization data in Table I clearly demonstrate that there is very variable expression of TNF- $\alpha$ or MIP- $1 \alpha$ mRNA within the blood eosinophils of hypereosinophilic patients. These findings stand in contrast to the earlier study of TGF- $\beta_{1}$ expression by human eosinophils, in which $100 \%$ of the blood eosinophils from hypereosinophilic subjects demonstrated positive hybridization signals (11). We also found that blood eosinophils obtained from normal donors expressed significant levels of TNF- $\alpha$ mRNA by in situ hybridization, while examination of the same specimens for MIP- $1 \alpha$ mRNA (this study) or TGF- $\beta_{1}$ mRNA (our previous study [11]) revealed only weak or undetectable expression of these cytokines. These findings raise the possibility that the circulating eosinophils of normal donors, as well as those from patients with hypereosinophilia, can influence biological responses through TNF- $\alpha$-dependent mechanisms. On the other hand, the differences in the expression of mRNA for TNF- $\alpha$ or MIP$1 \alpha$ by blood eosinophils of normal subjects suggest that the expression of these two cytokines may be differentially regulated. This concept is further supported by the Northern blot analysis of eosinophils derived from a patient with HES. Treatment of these cells with either calcium ionophore or PMA had only weak effects upon levels of TNF- $\alpha$ message. By contrast, either agent stimulated a marked induction of MIP-1 $\alpha$ mRNA, an effect that was sustained through $20 \mathrm{~h}$ of culture.

The expression of TNF- $\alpha$ and MIP- $1 \alpha$ mRNA was not restricted to blood-borne eosinophils. In situ hybridization analysis of human nasal polyps revealed intense labeling of eosinophils with antisense probes for each of these cytokines, and in contrast to the variable proportions of blood eosinophils that expressed mRNA for TNF- $\alpha$ or MIP- $1 \alpha$, the great majority of eosinophils in the nasal polyp specimens was intensely labeled for each cytokine. This finding suggests that eosinophil TNF- $\alpha$ and MIP-1 $\alpha$ cytokine expression can be upregulated by mi- croenvironmental factors encountered by eosinophils infiltrating tissues in vivo.

Many of the specific biologic effects attributable to TNF- $\alpha$ share the common feature of promoting inflammation. Thus, TNF- $\alpha$ can induce cytokine genes, protein synthesis and secretion in a wide variety of cell types, alter the expression of cell surface molecules critical to cell-cell interactions (e.g., adhesion proteins and histocompatibility antigens), promote degradation of extracellular matrix components, induce activation of neutrophils, macrophages or eosinophils, induce angiogenesis, and stimulate the proliferation of several different cell types $(38,39)$. MIP- $1 \alpha$ is a member of the C-C subfamily of the intercrine or chemokine cytokine supergene family $(40,41)$. Although its biological effects have been less extensively characterized than those of TNF- $\alpha$, MIP- $1 \alpha$ also appears to exert a spectrum of proinflammatory properties, including the ability to promote leukocyte recruitment and activation and to enhance macrophage proliferation, cytotoxicity, and cytokine secretion (40-43). Indeed, it has recently been shown that MIP$1 \alpha$ can stimulate macrophages to release TNF- $\alpha$, IL- 6 and IL$1 \alpha$ (26). If eosinophils that express MIP- $1 \alpha$ mRNA also release the product, this might represent a mechanism by which eosinophils can augment the ability of macrophages and perhaps other leukocytes at sites of inflammation to release additional proinflammatory mediators.

Eosinophils have long been regarded as potentially important participants in a variety of inflammatory processes. While eosinophils can promote inflammation through the release of previously characterized products such as cytoplasmic granule proteins or eicosanoids, our findings suggest that some of the effects of eosinophils in inflammation may reflect their ability to elaborate proinflammatory cytokines such as TNF- $\alpha$ and MIP-1 $\alpha$. On the other hand, the factors that regulate eosinophil cytokine expression in vivo are not understood, and both TNF$\alpha$ and MIP- $1 \alpha$ can be produced by several cell types in addition to the eosinophil. As a result, the extent to which eosinophils, as opposed to other cells, constitute a significant source of TNF- $\alpha$ or MIP- $1 \alpha$ in individual biological responses can only be assessed by directly evaluating the patterns of cytokine expression in each of these conditions.

Nevertheless, the relative importance of the eosinophil as a source of TNF- $\alpha$ or other cytokines generally may be greatest in those responses in which eosinophils represent an especially prominent component of the inflammatory infiltrate. Accordingly, it may be of particular interest to investigate eosinophils participating in responses to certain parasites or tumors, or in the lesions of asthma and other allergic diseases (1-4). TNF- $\alpha$ may contribute to eosinophil recruitment in these settings by inducing upregulation of the leukocyte adherence structures, endothelial-leukocyte adhesion molecule-1, intercellular adhesion molecule-1, and vascular cell adhesion molecule- 1 , on vascular endothelial cells (44-46). Although mast cells may represent an important initial source of TNF- $\alpha$ in some of these conditions ( $18-22,47,48)$, production of TNF- $\alpha$ by recruited eosinophils might serve to augment and perpetuate leukocyte infiltration at these sites. Beyond effects on inflammation per se, TNF- $\alpha$ production by eosinophils might have additional clinically significant consequences, such as enhancement of eosinophil-dependent toxicity to Schistosoma mansoni larvae (49) or granuloma formation during experimental models of schistosomiasis $(50,51)$. In mice, host resistance to certain 
tumor cells can be greatly enhanced by transfecting the tumor cells with IL-4, and the inflammatory infiltrates at sites of tumor rejection contain large numbers of eosinophils (52). This finding, taken together with studies demonstrating prominent infiltrates of eosinophils in association with certain spontaneous malignancies in man (reviewed in reference 9), suggest that eosinophil-derived TNF- $\alpha$ might contribute to host defense against neoplasms.

In atopic asthmatics, increased airways hyperresponsiveness has been associated with increased numbers of activated eosinophils in bronchial biopsies (53) and increased levels of eosinophil-derived mediators in bronchoalveolar lavage fluids (54). Moreover, recent evidence from rats indicates that TNF$\alpha$ can promote bronchial hyperresponsiveness (55). These findings raise the possibility that eosinophil-derived TNF- $\alpha$ might not only amplify leukocyte infiltration in asthma, but also might contribute to the bronchial hyperreactivity, which is characteristic of this disorder (56).

\section{Acknowledgments}

Supported by National Institutes of Health AI22674, AI23990, AI31982, AI33372, AI20241, HL46563, DE08680, and DE00318, and the Beth Israel Hospital Pathology Foundation. J. J. Costa is a recipient of the Scholar in Allergy Award from the American Academy of Allergy and Immunology and Marion-Merrell Dow. W. J. Beil is supported by Deutsche Forschungsgemeinschaft (Bonn, Germany).

\section{References}

1. Weller, P. F. 1991. The immunobiology of eosinophils. N. Engl. J. Med. 324:1110-1118.

2. Gleich, G. J., and C. R. Adolphson. 1986. The eosinophilic leukocyte: structure and function. Adv. Immunol. 39:177-253.

3. Spry, C. 1989. Eosinophils. Oxford University Press, New York.

4. Nutman, T. B., E. A. Ottesen, and S. G. Cohen. 1988. Eosinophilia and eosinophil-related disorders. In Allergy: Principles and Practice. E. Middleton, Jr., C. E. Reed, E. F. Ellis, N. F. Adkinson, Jr., and J. W. Yuninger, editors. 3rd ed. Mobsy-Year Book, Inc., St. Louis, MO. 861-890.

5. Fauci, A. S., J. B. Harley, W. C. Roberts, V. J. Ferrans, H. R. Gralnick, and B. H. Bjornson. 1982. The idiopathic hypereosinophilic syndrome: clinical pathophysiologic and therapeutic considerations. Ann. Intern. Med. 97:78-92.

6. Weller, P. F. 1992. Eicosanoids, cytokines and other mediators elaborated by eosinophils. In Eosinophils: Biological and Clinical Aspects. S. Makino and T. Fukada, editors. CRC Press, Boca Raton, FL. 125-134.

7. Galli, S. J., J. R. Gordon, B. K. Wershil, J. J. Costa, A. Elovic, D. T. W. Wong, and P. F. Weller. Mast cell and eosinophil cytokines in allergy and inflammation. In Eosinophils: Immunological and Clinical Aspects. G. J. Gleich and A. B. Kay, editors. Marcel Dekker, Inc., New York. In press.

8. Del Pozo, V., B. De Andres, E. Martin, N. Maruri, J. M. Zubeldia, P. Palomino, and C. Lahoz. 1990. Murine eosinophils and IL-1: $\alpha$ IL-1 mRNA detection by in situ hybridization. J. Immunol. 144:3117-3122.

9. Wong, D. T. W., P. F. Weller, S. J. Galli, A. Elovic, T. H. Rand, G. T. Gallagher, T. Chiang, M. Y. Chou, K. Matossian, J. McBride, and R. Todd. 1990. Human eosinophils express transforming growth factor-alpha. J. Exp. Med. 172:673-681.

10. Elovic, A., S. J. Galli, P. F. Weller, A. L. C. Chang, T. Chiang, M. Y. Chou, B. Donoff, G. T. Gallagher, K. Matossian, J. McBride, et al. 1990. Production of transforming growth factor-alpha by hamster eosinophils. Am. J. Pathol. 137:1425-1434.

11. Wong, D. T. W., A. Elovic, K. Matossian, N. Nagura, J. McBride, M. Y. Chou, J. R. Gordon, T. H. Rand, S. J. Galli, and P. F. Weller. 1991. Eosinophils from patients with blood eosinophilia express transforming growth factor $\beta 1$. Blood. 78:2702-2707.

12. Ohno, I., R. G. Lea, K. C. Flanders, D. A. Clark, D. Banwatt, J. Dolovich, J. Denburg, C. B. Harley, Gauldie, and M. Jordana. 1992. Eosinophils in chronically inflamed human upper airway tissues express transforming growth factor $\beta 1$ gene. J. Clin. Invest. 89:1662-1668.

13. Moqbel, R., Q. Hamid, S. Ying, J. Barkans, A. Hartnell, A. Tsicopoulos, A. J. Wardlaw, and A. B. Kay. 1991. Expression of mRNA and immunoreactivity for the granulocyte/macrophage colony-stimulating factor in activated human eosinophils. J. Exp. Med. 174:749-752.

14. Kita, H., T. Ohnishi, Y. Okubo, D. Weiler, J. S. Abrams, and G. J. Gleich. 1991. Granulocyte/macrophage colony-stimulating factor and interleukin 3 release from human peripheral blood eosinophils and neutrophils. J. Exp. Med. 174:745-748.

15. Desreumaux, P., A. Janin, J. F. Colombel, L. Prin, J. Plumas, D. Emilie, G. Torpier, and M. Capron. 1992. Interleukin 5 messenger RNA expression by eosinophils in the intestinal mucosa of patients with coeliac disease. J. Exp. Med. 175:293-296.

16. Weller, P. F., T. H. Rand, T. Barrett, A. Elovic, D. T. W. Wong, and R. W. Finberg. 1993. Accessory cell function of human eosinophils: HLA-DR-dependent, MHC-restricted antigen presentation and interleukin-1 $\alpha$ expression. J. Immunol. 150:2554-2562.

17. Hamid, Q., J. Barkans, Q. Meng, S. Ying, J. S. Abrams, A. B. Kay, and R. Moqbel. 1992. Human eosinophils synthesize and secrete interleukin-6, in vitro. Blood. 80:1496-1501.

18. Gordon, J. R., and S. J. Galli. 1990. Mast cells as a source of both preformed and immunologically inducible TNF- $\alpha$ /cachectin. Nature (Lond.). 346:274-276.

19. Gordon, J. R., and S. J. Galli. 1991. Release of both preformed and newly synthesized tumor necrosis factor $\alpha$ (TNF- $\alpha$ )/cachectin by mouse mast cells stimulated by the $F_{c} R I$. A mechanism for the sustained action of mast cell-derived TNF- $\alpha$ during IgE-dependent biological responses. J. Exp. Med. 174:103107.

20. Wershil, B. K., Z.-S. Wang, J. R. Gordon, and S. J. Galli. 1991. Recruitment of neutrophils during IgE-dependent cutaneous late phase reactions in the mouse is mast cell dependent. J. Clin. Invest. 87:446-453.

21. Walsh, L. J., G. Trinchieri, H. A. Waldorf, D. Whittaker, and G. F. Murphy. 1991. Human dermal mast cells contain and release tumor necrosis factor $\alpha$ which induces endothelial leukocyte adhesion molecule-1. Proc. Natl. Acad. Sci. USA. 88:4220-4224.

22. Leung, D. Y. M., J. S. Pober, R. S. Cotran. 1991. Expression of endothelial-leukocyte adhesion molecule- 1 in elicited late phase allergic reactions. $J$. Clin. Invest. 87:1805-1809.

23. Ying, S., D. S. Robinson, B. Varney, Q. Meng, A. Tsicopoulos, R. Moqbel, S. R. Durham, A. B. Kay, and Q. Hamid. 1991. TNF- $\alpha$ mRNA expression in allergic inflammation. Clin. Exp. Allergy. 21:745-750.

24. Gossett, P., A. Tsicopoulos, B. Wallaert, C. Vannimenus, M. Joseph, A.-B. Tonnel, and A. Capron. 1991. Increased secretion of tumor necrosis factor $\alpha$ and interleukin- 6 by alveolar macrophages consecutive to the development of the late asthmatic reaction. J. Allergy Clin. Immunol. 88:561-571.

25. Gordon, J. R., P. R. Burd, and S. J. Galli. 1990. Mast cells as a source of multifunctional cytokines. Immunol. Today. 11:458-464.

26. Fahey, T. J. III, K. J. Tracey, P. Tekamp-Olson, L. S. Cousens, W. G. Jones, G. T. Shires, A. Cerami, and B. Sherry. 1992. Macrophage inflammatory protein 1 modulates macrophage function. J. Immunol. 148:;2764-2769.

27. Costa, J. J., K. Matossian, W. J. Beil, D. T. W. Wong, J. R. Gordon, A. M. Dvorak, P. F. Weller, and S. J. Galli. 1993. Human eosinophils can express the cytokines TNF- $\alpha$ and MIP-1 $\alpha$. J. Allergy Clin. Immunol. 91:A174. (Abstr.)

28. Lucey, D. R., A. Nicholson-Weller, and P. F. Weller. 1989. Mature eosinophils have the capacity to express HLA-DR. Proc. Natl. Acad. Sci. USA 86:1348-1351.

29. Collins, S. J., R. C. Gallo, and R. E. Gallagher. 1977. Continuous growth and differentiation of human myeloid leukaemic cells in suspension culture. Nature (Lond.). 270:347-349.

30. Pennica, D., G. E. Nedwin, J. S. Hayflick, P. H. Seeburg, R. Derynck, M. A. Palladino, W. J. Kohr, B. B. Aggarwal, and D. V. Goeddel. 1984. Human tumour necrosis factor: precursor structure, expression and homology to lymphotoxin. Nature (Lond.). 312:724-729.

31. Burd, P. R., H. W. Rogers, J. R. Gordon, C. A. Martin, S. Jayaraman S. D. Wilson, A. M. Dvorak, S. J. Galli, and M. E. Dorf. 1989. Interleukin 3-dependent and -independent mast cells stimulated with $\mathrm{IgE}$ and antigen express multiple cytokines. J. Exp. Med. 170:245-257.

32. Dugaiczyk, A., J. A. Haron, E. M. Stone, O. E. Dennison, K. N. Rothblum, and R. J. Schwartz. 1983. Cloning and sequencing of a deoxyribonucleic acid copy of glyceraldehyde-3-phosphate dehydrogenase messenger ribonucleic acid isolated form chicken muscle. Biochemistry. 22:1605-1613.

33. McCrone, E. L., D. R. Lucey, and P. F. Weller. 1988. Fluorescent staining for leukocyte chemotaxis: Eosinophil-specific fluorescence with aniline blue. $J$. Immunol. Methods. 114:79-88.

34. Hansel, T. T., I. J. M. de Vries, T. Iff, S. Rihs, M. Wandzilak, S. Betz, K. Blaser, and C. Walker. 1991. An improved immunomagnetic procedure for the isolation of highly purified eosinophils. J. Immunol. Methods. 145:105-110.

35. Djeu, J. Y., D. Serbousek, and D. K. Blanchard. 1990. Release of tumor necrosis factor by human polymorphonuclear leukocytes. Blood. 76:1405-1409.

36. Dubravec, D. B., D. R. Spriggs, J. A. Mannick, and M. L. Rodrick. 1990 Circulating human peripheral blood granulocytes synthesize and secrete tumor necrosis factor $\alpha$. Proc. Natl. Acad. Sci. USA. 87:6758-6761. 
37. Bosma, P. J., and T. Kooistra. 1991. Different induction of two plasminogen activator inhibitor 1 mRNA species by phorbol ester in human hepatoma cells. J. Biol. Chem. 266:17845-17849.

38. Gamble, J. R., J. M. Harlan, S. J. Klebanoff, and M. A. Vadas. 1985 Stimulation of the adherence of neutrophils to umbilical vein endothelium by human recombinant tumor necrosis factor. Proc. Natl. Acad. Sci. USA. 82:86678671.

39. Beutler, B., and A. Cerami. 1989. The biology of cachectin/TNF- $\alpha$ a primary mediator of the host response. Annu. Rev. Immunol. 7:625-655.

40. Wolpe, S. D., and A. Cerami. 1989. Macrophage inflammatory proteins 1 and 2: members of a novel superfamily of cytokines. FASEB (Fed. Am. Soc. Exp. Biol.) J. 3:2565-2573.

41. Oppenheim, J. J., O. C. Zachariae, N. Mukaida, and K. Matsushima. 1991. Properties of the novel proinflammatory supergene "intercrine" cytokine family. Annu. Rev. Immunol. 9:617-648.

42. Wolpe, S. D., G. Davatelis, B. Sherry, B. Beutler, D. Hesse, H. T. Nguyen, L. L. Moldawer, C. F. Nathan, S. F. Lowry, and A. Cerami. 1988. Macrophages secrete a novel heparin-binding protein with inflammatory and neutrophil chemokinetic properties. J. Exp. Med. 167:570-581.

43. Saukkonen, K., S. Sande, C. Cioffe, S. Wolpe, B. Sherry, A. Cerami, and E. Tuomanen. 1990. The role of cytokines in the generation of inflammation and tissue damage in experimental gram positive meningitis. J. Exp. Med. 171:439448.

44. Kyan-Aung, U., D. Haskard, R. N. Poston, M. H. Thornhill, and T. H. Lee. 1991. Endothelial leukocyte adhesion molecule-1 and intercellular adhesion molecule-1 mediate the adhesion of eosinophils to endothelial cells in vitro and are expressed by endothelium in allergic cutaneous inflammation in vivo. $J$. Immunol. 146:521-528.

45. Weller, P. F., T. H. Rand, S. E. Goelz, G. Chi-Rosso, and R. Eobb. 1991 Human eosinophil adherence to vascular endothelium mediated by binding to vascular cell adhesion molecule 1 and endothelial leukocyte adhesion molecule 1 . Proc. Natl. Acad. Sci. USA. 88:7430-7433.

46. Bochner, B. S., F. W. Luscinskas, M. A. Gimbrone, Jr., W. Newman, S. A. Sterbinsky, C. P. Derse-Anthony, D. Klunk, and R. P. Schleimer. 1991. Adhesion of human basophils, eosinophils, and neutrophils to interleukin 1-activated hu- man vascular endothelial cells: Contributions of endothelial cell adhesion molecules. J. Exp. Med. 173:1553-1556.

47. Benyon, R. C., E. Y. Bissonnette, and A. D. Befus. 1991. Tumor necrosis factor-dependent cytotoxicity of human skin mast cells is enhanced by anti-IgE antibodies. J. Immunol. 147:2253-2258.

48. Galli, S. J. New concepts about the mast cell. 1993. N. Engl. J. Med. 328:257-265.

49. Silberstein, D. S., and J. R. David. 1986. Tumor necrosis enhanced eosinophil toxicity to Schistosoma mansoni larvae. Proc. Natl. Acad. Sci. USA. 83:1055-1059.

50. Amiri, P., R. M. Locksley, T. G. Parslow, M. Sadick, E. Rector, D. Ritter, and J. H. McKerrow. 1992. Tumor necrosis factor $\alpha$ restores granulomas and induces parasite egg-laying in schistosome-infected SCID mice. Nature (Lond.). 356:604-607.

51. Cheever, A. W., Y. Xu, A. Sher, and J. G. Macedonia. 1991. Analysis of egg granuloma formation in Schistososma japonicum-infected mice treated with antibodies to interleukin-5 and gamma interferon. Infect. Immun. 54:4071-4074.

52. Tepper, R. I., R. L. Coffman, and P. Leder. 1992. An eosinophil-dependent mechanism for the antitumor effect of interleukin-4. Science (Wash. DC). 257:548-551.

53. Bradley, L., M. Azzawi, M. Jacobson, B. Assouf, J. V. Collins, A. M. Irani, L. B. Schwartz, S. R. Durham, P. K. Jeffrey, and A. B. Kay. 1991. Eosinophil, T-lymphocytes, mast cells, neutrophils, and macrophages in bronchial biopsy specimens from atopic subjects with asthma: comparison with biopsy specimens from atopic subjects without asthma and normal control subjects and relationship to bronchial hyperresponsiveness. J. Allergy Clin. Immunol. 88:661674.

54. Broide, D. H., G. J. Gleich, A. J. Cuomo, D. A. Coburn, E. C. Federman L. B. Schwartz, and S. I. Wasserman. 1991. Evidence of ongoing mast cell and eosinophil degranulation in symptomatic asthma airway. J. Allergy Clin. Immunol. 88:637-648.

55. Kips, J. C., J. Tavernier, and R. A. Pauwels. 1992. Tumor necrosis factor causes bronchial hyperresponsiveness in rats. Am. Rev. Respir. Dis. 145:332-336.

56. Busse, W. W., and J. B. Sedgwick. 1992. Eosinophils in asthma. Ann. Allergy. 68:286-290. 